\title{
DISPROPORTIONATE MIGRATION PRESSURE AS A CHALLENGE FOR THE NATIONAL SECURITY OF THE REPUBLIC OF BULGARIA
}

\author{
Nikolay MARIN \\ South-West University "Neofit Rilski”, Blagoevgrad, Bulgaria \\ marin@law.swu.bg
}

\begin{abstract}
Since 2011 a sustainable growth of illegal immigrants in the EU has been observed. As a result, Bulgaria has become one of the most affected member states of the EU. This article aims to research the main factors, resulted from the illegal immigration, which are changing the national security environment in Bulgaria. This paper is focused on the improvement of legal and political mechanisms for cooperation between the EU member states, coming from the Common asylum and immigration policy and building of the Area of Freedom, Security and Justice in the EU.
\end{abstract}

Keywords: migration crisis, national security, migrants, refugees, ECHR, CJEU

1. Introduction and development of the problem related to migration crisis in the European Union

The disproportionate migration pressure is one of the most significant challenges to ensuring the security of the Member States of the European Union. Particularly vulnerable are the countries that are preferred as the ultimate goal as well as the countries through which the route of migration passes. To a great extent this also applies to the national security of the Republic of Bulgaria, which is located near the main road through which the migrant flow passes. The current situation related to the unprecedented pressures of large numbers of people wishing to migrate from less-developed countries in the European Union is strongly undervalued at the moment, especially from representatives of various institutions and specialised agencies of the European Union. Proof of this is the existence of different models for solutions, which, to a certain extent, are mutually exclusive. There is the impression that there is a deficit in decision-making, with a focus mainly on speaking and discussing problems without proceeding to take concrete measures to help countries meeting the migratory pressure or countries that are among the most preferred ones by migrants.

Moreover, the opposition and contradictions among EU Member States in connection with the migration crisis come to the fore. For example, in September 2015 Croatian police officers escorted migrants that were on buses or trains to cross the border with Hungary, which in turn was building protective fences with the aims to restrict the access of migrants to its territory [1]. Controversies are evident in domestic political terms, too. The Prime Minister of Bavaria, Horst Seehofer, very clearly opposed the policy of the Federal Chancellor Angela Merkel towards the migration crisis.

Thus, these examples reflect the existing deficit of a clear policy and generally accepted actions to tackle the biggest migration and refugee wave which, in no small part, brings negative energy, impending the establishment of an area of freedom, security and justice. On the other 
hand, they express the failure of European states to overcome narrow national interests and to respond and undertake actions once they have been accorded at a European Union level. The theme of migration crisis engages the attention of the highest political level as at summits of the European Council, including March 2016, there were identified actions to address the migration crisis. In this regard, there was given a special place of cooperation with Turkey, which is not the most apt solution. An agreement was signed, called ad hoc, particularly for the specific situation concerning the migration crisis at this moment. At the same time the prolonged negotiated classic readmission agreement between the EU and Turkey is still not in force despite the fact that it has been concluded in November 2015. This is expected to enter into force by June $1^{\text {st }}$ 2016 [2]. All of this means that it is likely that soon Turkey would ask for a review of the current agreement, which shows a lack of stability in solving these complex and specific relations. Such a classification is actually given by the Turkish daily newspaper just days after signing the agreement [3].

\section{Some problems of terminological character concerning migrants and refugees}

Another significant element in terms of law is a need to more accurately distinguish between different migrant groups by separating refugees, who are in need of protection, from economic migrants, who contribute to the discreditation and distrust of all those, who, due to fear for their lives, have undertaken a search for safer countries for them and their families.

Recently there has been observed a mixing of basic concepts such as "migrant" and "refugee", which often leads to their perception as synonyms. This requires some terminological clarifications.
A refugee is every person that in case of "well-founded fear of being persecuted for reasons of race, religion, nationality, membership of a particular social group or political opinion, is outside the country of his nationality and is unable or, owing to such fear, is unwilling to avail himself of the protection of that country; or who, not having a nationality and being outside the country of his former habitual residence as a result of such events, is unable or, owing to such fear, is unwilling to return to it." (Art. 1. (A) (2) of the Convention relating to the Status of Refugees). The Convention relating to the Status of Refugees is the main international legal instrument that defines both the refugee status and the basic principles of refugee protection. Refugee protection may include various aspects:

1. Certainly they will not be returned to the state under the existing dangers from which they fled;

2. Access to fair and effective mechanisms for the granting of asylum;

3. Measures to ensure that their fundamental rights are guaranteed and respected in a way in which to provide them with a guarantee of a decent lifestyle.

An asylum seeker is every person who claims to be a refugee and seeks international protection from persecution or serious harm in their home country. While waiting for being granted or denied refugee status, such a person is defined as an "asylum seeker".

Unlike refugees, migrants leave the country not because of a direct threat of persecution or death, but to improve their lives, e.g. by finding work, sometimes for training, gathering with other family members and so on. Unlike refugees, who can not return to their country where they can be safe, with regard to migrants - there are no such obstacles.

Due to the particular situation refugees are in and their motives to leave the country, the protection of which they can not enjoy, their status, as well as the 
mechanisms for their protection are determined largely by international law acts, among which are the European Convention on Human Rights (ECHR) and the jurisprudence of both the European Court of Human Rights and Court of European Union. The future of human rights protection and their terminological clarification in Europe will depend on the resumption of the dialogue between the CJEU and the European Court of Human Rights, which was discontinued after Opinion 2/13 of 2014, the Court in Luxembourg, regardless of the fact that there is a well-established system of mutual reference to their jurisprudence [4]. A thorough critical analysis of Opinion $2 / 13$ of 2014 has been given by the authoritative Bulgarian scientist Prof. Gabriela Belova [5].

\section{National Security of the Republic of Bulgaria and disproportionate migration pressure - possible solution}

The disproportionate migratory pressure on the national security of the Republic of Bulgaria is a matter of paramount importance. In this sense, the dynamically changing environment, including the neighboring to Bulgaria countries, further complicate the solution to these problems. Meanwhile, in the National Security Strategy of the Republic of Bulgaria in Section III.1 External security context in item 34 it is stated that "The unstable economic and political situation and the low standard of living in Third World states and regions generate a migration pressure on the country as an external EU border" [6].

The political interaction and achieving internal consistency in the EU is a challenge that clearly stands out from the presence of multidirectional trends and issues relating to both current and future functioning of the EU and its response to a number of potential internal and external threats. Some of these threats are significant even for the content and values of the European integration and the further architecture and legal personality of the European Union [7].

The presence of a number of multifaceted challenges and asymmetric threats, despite its negative impact on the functioning of the European Union itself lead to a deterioration in the level of security and stability in the EU's neighbouring regions.

In this regard there should be paid special attention to a new phenomenon in the contemporary reality, namely mass migration to the old continent of unstable political and economic regions of the so called Third World, adjacent to Europe. However, it should be clear that this phenomenon itself is not a new phenomenon - migration movements in Europe and to Europe have been present if not always, then strongly expressed in certain periods of its development. The new nowadays is reflected in an unprecedented scale, only partially the humanitarian purpose and in fact nontransparent purposes, that is, in principle, the new motivation predetermined by the new circumstances in the otherwise old frame of the resulting exodus of large numbers of people [8]. These new circumstances related to: the ethnic characteristics of migration flows, obvious or hidden economic interests, the existence of armed conflicts among several countries in certain regions, sharp conflicts on the basis of different religious and confessional specifics, traditional or emerging political antagonisms, social unsolved or unsolvable currently problems, rivalry for influence and supremacy between the great powers, etc. [9].

All of this is happening against the background of the general deterioration of the level of security and stability in regions neighboring the EU, not only from a refugee perspective, but they also essentially threaten the internal security of the EU. 
As a possible solution to the pointed out characteristics of migration processes towards the European Union is to improve the efficiency [10] in the implementation of the common policy on migration and asylum and the establishment of Rapid Border Intervention Teams to introduce more effective arrangements for protection, especially of the external borders of the European Union. Next, there is a need to improve the cooperation among EU Member States, as the leading point should be the solidarity and the involvement of all Member States to support the further existence of the Schengen area [11]. Finding a durable solution is also associated with more rapid implementation of the so called hotspots, especially for timely identification and registration of individuals. Practically this is the first step that could lead to normalising the problem, by restricting persons who have the reason and qualify for international protection from those who are economic migrants and should be returned back to the country of origin. The second element is to further develop the area of freedom, security and justice, but taking into account the changed conditions and the need for a new clearer long-term programme as the Stockholm Programme, which was the document of strategic importance, was for the period 2009 -2014.

\section{Conclusion}

The manner in which the EU deals with the migration crisis holds great significance for the European countries. It is even more important for the frontline countries like Bulgaria, which devote huge resources to protect their borders. Those countries are situated in a susceptible position in which, on the one hand, Brussels cannot provide a clear strategy and action plan for all member states; on the other hand, the migrant flows are not slowing down. Bulgaria finds itself in a state of limbo, which leaves it vulnerable on both sides.

Thus, it is crucial what signal the EU will send both to illegal immigration and to its Member States, which are exposed to massive security risks. Despite having all legal levers mentioned above, they seem insufficient to deal with these circumstances. The need for additional tools is so evident that the EU must devise and implement them urgently.

The EU is currently at a very important crossroad which will determine not only the future of the organisation, but also of the continent itself. The initial approach towards the problem by the most powerful EU leaders was based on assumptions about labour force, GDP, taxes, i.e. there is an emphasis laid on economic issues rather than issues concerning stability and Member States' national security within the new context of changing its environment and conditions. Excluding the security issues out of the equation turned out to be a disastrous mistake as some events in 2015-16 demonstrated. Europe needs to implement a sound strategy for an integral approach towards the illegal immigration and the secondary consequences it brings. They will be long-term and maybe impossible to predict.

Bulgaria, as a country with declining demographic trends, needs a unified European plan, which brings support and, at the same time, provides the country with the ability to defend its borders. Stopping the mass illegal immigration towards Europe is among the biggest concerns for Bulgaria and many other countries. Disagreement inside the $\mathrm{EU}$ on this topic is among the biggest security threats the continent will have to deal with.

\section{References}


[1] Croatia "forced" Hungary to accept thousands of migrants, available at: http://www.mediapool.bg/harvatiya-prinudi-ungariya-da-prieme-hilyadi-migrantinews239445.html

[2] DECISION No 2/2016 OF THE JOINT READMISSION COMMITTEE SET UP BY THE AGREEMENT BETWEEN THE EUROPEAN UNION AND THE REPUBLIC OF TURKEY ON THE READMISSION OF PERSONS RESIDING WITHOUT AUTHORISATION of on the implementing arrangements for the application of Articles 4 and 6 of the Agreement from 1 June 2016, Official Journal of the European Union, L 95/11, 9.04.2016

[3] Unsustainable agreement between Turkey and the EU, http://www.hurriyetdailynews.com/unsustainable-agreement-between-turkey-and-theeu.aspx?PageID $=238 \& N I D=96829 \& N e w s C a t I D=468$

[4] Marin, N., The Court of the European Union and the European Court of Human Rights to the new challenges to create a Pan-European legal Framework to protect human rights, State Political and Legal problems of contemporary Europe, State University of Penza, 2013, p. 95-101

[5] Белова, Г., Някой бележки след Становище 2/13 на Съда на ЕС, списание Общество и право, бр. 3/2015 г., издание на Съюза на юристите в България, София, 2015 г., с. 3-14

[6] National Security Strategy of the Republic of Bulgaria, approved by National Assembly Decision on $8^{\text {th }}$ March 2011, available at: http://www.strategy.bg/StrategicDocuments/View.aspx?lang=bg-BG\&Id=671

[7] Марин, Н., Христова, А., Анализ на правната уредба на Общата външна политика и политика на сигурност според Договора от Лисабон , Сборник от публикации в рамките на проект по Наредба № 9 на МОН 2010 г., „Изследване на Общата външна политика, политиката на сигурност и съседство на Европейския съюз след Лисабонския договор“, Университетско издателство „Неофит Рилски”, Благоевград, 2010 г., с.35-36

[8] GEORGIEVA, G., Multilingualism as a Significant Element to European Integration, the $21^{\text {st }}$ International Conference the Knowledge-Based Organization 2015, Sibiu, Conference Proceedings 1, Management and Military Sciences, "Nicolae Bălcescu" Land Forces Academy Publishing House, pp. 210-213, ISSN 1843-6722

[9] Стоилова, В., Хуманитарната интервенция или хуманитарна помощ (в дейността на Европейския съюз), Юбилеен сборник „Право, управление и медии през XXI век” Университетско издателство „Неофит Рилски”, Благоевград, 2012 г., с.120-121

[10] Василев, В., Управление на човешките ресурси в условията на криза, Центьр по публична администрация, годишник, С., 2012 г. том 7

[11] Станин, М., „Обекти на правната действителност”, изд. Ираник, Благоевград, 2010 г., c. 23 